\title{
A social network analysis applied to understand the relationships in fish farming tank-nets business in Brazil ${ }^{1}$
}

\author{
Análise de rede social aplicada para compreender as relações nos negócios de \\ piscicultura em tanque-rede no Brasil

\section{Análisis de la red social aplicada para comprender las relaciones en los negocios de piscicultura en tanque-red en Brasil}

\author{
Raiane Real Martinelli ${ }^{2}$ \\ Gessuir Pigatto ${ }^{3}$ \\ Timóteo Ramos Queiroz ${ }^{3}$ \\ Mário Mollo Neto ${ }^{3}$
}

Recebido em 07/06/2018; revisado e aprovado em 04/11/2018; aceito em 17/12/2018

DOI: http://dx.doi.org/10.20435/inter.v20i3.2038

\begin{abstract}
The present article aims to analyze the insertion of tilapia tank-nets producers in social networks and their influence on the information transfer within the network, from a group of fish farmers located in a reservoir in southeastern Brazil. Exploratory methods characterize this research, which has a qualitative approach based on a multi-case study. Roster method conducts the network research taking into account the limited number of actors in the network and the identification of all. This article allows an understanding of the influence of frequency, time and value attributed to the exchange of information among fish farmers. The trust degree in the relationships between fish farmers was measured through a Social Network Analysis (SNA) with the help of the UCINET ${ }^{\circledR}$ software. The results show that the transmitters of more information are the same that present themselves as central in the network and those who have the most valuable information. Keywords: social networks; fish farming; social capital; Social Network Analysis.

Resumo: O presente artigo tem como objetivo analisar a inserção de produtores de tilápias em tanquesredes em redes sociais e sua influência na transferência de informações dentro da rede, de um grupo de piscicultores localizados em um reservatório no sudeste do Brasil. O artigo se caracteriza como exploratório, de abordagem qualitativa, a partir de um estudo multicaso. A pesquisa de redes foi conduzida pelo método Roster, apropriado levando-se em consideração o número limitado de atores na rede e a identificação de todos. Este artigo possibilita uma compreensão da influência da frequência, tempo e valor atribuído às trocas de informações entre os piscicultores. O grau de confiança nas relações entre piscicultores foi medido a partir de Análise de Redes Sociais (SNA) e utilização de software UCINET ${ }^{\circledR}$. Os resultados mostram que os transmissores de mais informações são os mesmos que se apresentam como centrais na rede e aqueles que possuem as informações mais valiosas.
\end{abstract}

Palavras-chave: redes sociais; piscicultura; capital social; Análise de Redes Sociais.

Resumen: El presente artículo tiene como objetivo analizar la inserción de productores de tilapias en tanques-redes en redes sociales y su influencia en la transferencia de informaciones dentro de la red, de un grupo de piscicultores ubicados en un reservorio en el sudeste de Brasil. El artículo se caracteriza como exploratorio, de abordaje cualitativo, a partir de un estudio de casos múltiples. La investigación de redes fue conducida por el método Roster, apropiado teniendo en cuenta el número limitado de actores en la red y la identificación de todos. Este artículo permite una comprensión de la influencia de la frecuencia, el tiempo y el valor atribuido a los intercambios de información entre los piscicultores. El grado de confianza en las relaciones entre piscicultores fue medido a partir de Análisis de Redes Sociales (SNA) y utilización de software $U C I N E T^{\circledR}$. Los resultados muestran que los transmisores de más información son los mismos que se presentan como centrales en la red y aquellos que poseen las informaciones más valiosas.

Palabras clave: redes sociales; piscicultura; capital social; Análisis de Redes Sociales.

\footnotetext{
${ }^{1}$ The authors would like to thank FAPESP (2014/16075-2) for the research grant awarded to the first author to develop the research that originated this paper.

${ }^{2}$ Universidade Estadual de Maringá (UEM), Maringá, Paraná, Brasil.

${ }^{3}$ Universidade Estadual Paulista (UNESP), Tupã, São Paulo, Brasil.
} 


\section{INTRODUCTION}

The modern approach to management theory presents the organization/enterprise as an open system, starting from the premise that there is an interdependence between the microsystem (organization) and the macro system (environment in which it is inserted) (CURY, 2012; GODFREY; MELIN, 2008). Morgan (1996) and Daft (2008) emphasize that the concept of openness determines that organization and environment must be in a constant and mutual state of interaction and dependence since, for an open system to survive, it needs to interact with the environment, adapt to it, consume and export resources to it. Godfrey and Melin (2008) complement that the organization actions can be better adapted and the objectives reached with the knowledge, tools, and processes of the microsystem, besides the understanding of the context where it is inserted.

From these arguments, it can be emphasized that the interaction of each organization with the environment implies in relating with other organizations, thus arising the theme of inter-organizational relations. For Rzepka (2017) inter-organizational relations broaden the understanding that cooperation among independent entities tends to be considered as one of the most important development trends in contemporary value creation mechanisms. The configurations of inter-organizational relationships are diverse and vary according to the purpose of the organizations involved and the type of interaction between them.

One type of relationship between organizations that has been gaining prominence is the so-called Social Network (RIVERA; SODERSTROME; UZZI, 2010; MONAGHAN; LAVELLE; GUNNIGLE, 2017). According to Grandori and Soda (1995), organizations linked by social networks maintain informal and purely social interactions, devoting themselves to the exchange of information and resources without the use of any formal contract.

Despite its informality and apparent simplicity, much is argued about the importance of social networking for the survival of organizations of all kinds.

Perhaps the most fundamental characteristic of network theory (though not unique to it) is the focus on relationships among actors as an explanation of actor and network outcomes, according Borgatti, Brass and Halgin (2014). The functioning of organizations, according to Borgatti and Foster (2003) and Borgatti et al. (2009) involves more than formal hierarchical structures within them or inter-organizational relationships formally governed by contracts. Thus, much of what is decided within or between organizations comes from informal interactions.

In this way, the perspective of social networks is focused on the interactions between the actors and not on the attributes of each of them individually, where the goals are not set in isolation and their behavior is not always strictly selfish (ABROMOVAY, 2000; KENIS; OERLEMANS, 2008). Also for Ahuja (2000), several studies have indicated that the agents' positions in interorganizational networks can influence the behavior of the agents and their results.

Studies on interorganizational relationships usually investigate industries, companies providing various services, as well as their relationship with public agencies. Despite the scarce theory in the agribusiness sector, the study of social networks is also extremely important, since informal relationships, in many cases, have the power to consolidate organizational dynamics and interfere in decision-making processes (NEIVA; BRITO, 2008). Some studies have tried to fill this gap, such as Maertens and Barrett (2013), Xiong, Wang and Zhu (2016) and Johny, Wichmann and Swallow (2017). 
From this reflection, the focus area of the study was fish farming in Brazil, specifically the production of tilapia in a tank-net. In order to better contextualize this object of study, it is pointed out that fish farming is the main aquaculture activity, accounting for $86.6 \%$ of all Brazilian continental aquaculture (BRASIL, 2011), with tank-nets being the main modality of growing fish farming in Brazil. Ayroza (2009) specifies that tank-nets are used in intensive cropping systems and should be allocated to areas with high and continuous water renewal.

A very popular species in national fish farming, the Nile tilapia (Oreochromisniloticus), has well-defined (genetics) technology for tank-net production. It should also be noted its rusticity (adaptation to intensive cultivation and resistance to diseases) and good performance (high feed conversion rate and fingerlings production all year round) (AYROZA et al., 2005; SANDOVAL JR. et al., 2013).

Sampaio and Braga (2006) point to the fact that water reservoirs destined to the generation of electric power, irrigation, and other purposes have been used for the installation of fish farming projects in tank-nets in a progressive way. A large number of damned areas in the hydroelectric plants can be considered one of the factors that contribute to the growth of projects with tanknets. The implementation of these tanks in areas already impacted by dams reflect less use of permanent preservation areas and also minimize the exploitation of natural fish stocks, which leads to good environmental appeal (AYROZA; AYROZA, 2012).

The data show that fish world consumption has grown significantly over the years. Food and Agriculture Organization of the United Nations (FAO, 2016) data show that in 1960 were consumed $9.9 \mathrm{~kg}$ per person per year, and in 2014, consumption reached $20 \mathrm{~kg}$. In addition to consumption, the production also grew (8\%) in the same period, reaching a volume of approximately 167.0 million tons of fish in 2014 (FAO, 2016).

This world average, however, hides a marked discrepancy in the distribution of fish consumption by regions (CREPALDI et al., 2006). Asian and Nordic countries have per capita fish consumption above $60 \mathrm{~kg}$ per year (FAO, 2016), while Brazil recorded an average consumption of $11.2 \mathrm{~kg}$ per person in 2011 (BRASIL, 2013). Even with low per capita consumption, Brazil has seen an increase in the demand for fish and seafood. The data for 2011 represents an increase of $14.5 \%$ over the one registered in the previous year (BRASIL, 2013).

The fish can come from two activities: extractive fishing and aquaculture, the latter having grown an average of $8 \%$ per year in Brazil from 2004 to 2014. This growth made fish production the largest increase in the national meat market (KUBITZA, 2015). In 2011, 1.4 million tons of fish were produced in Brazil, with continental aquaculture accounting for about $39 \%$ of this production, reaching 544.5 thousand tons (BRASIL, 2011).

Based on what has been presented on the importance of fish farming in Brazil and its growth in national production and consumption, as well as the contributions of the Social Network theory in relation to interorganizational relationships and network performance, the present research has the following question: How the insert of tilapia fish farmers in social networks impact on the transmission of information between members? The article aims to analyze the insertion of tilapia tank-nets producers in social networks and their influence on the information transfer within the network. As a scope of analysis, a group of fish farmers located in the reservoir of hydroelectric power plants (HPP), called HPP Canoas I, located between the states of Paraná and São Paulo, southern and southeastern Brazil, will be investigated. 
The paper is divided into five main parts, including this introduction. The second section presents a theoretical review on aspects of social network theory and Social Network Analyses (SNA). The third part presents the methodology used in the study. After the methodology, the results are described and discussed and, finally, the conclusions of the study are presented.

\section{THEORETICAL REVIEW}

\subsection{Social networks}

According to Granovetter (1985), throughout the history of economy, two extreme and antagonistic visions permeated the analyzes of organizations behavior in their social relations. On one hand, classical and neoclassical economists present a sub-socialized view of the human action on the economy, where social relations would affect it minimally and the decisions of economic agents would be taken from extremely rational behavior (GRANOVETTER, 1985). On the other hand, modern sociologists and economists emerge with a super socialized view, where social pressure is greatly valued and treated as a determinant on economic behavior.

Granovetter (1985) however, defends a balance between the two extremes cited when says that economic agents are not like atoms outside a social context, but they are not purely conditioned by the social categories in which they are inserted as if ready-made scripts guided their actions.

From this thought, it can be said that the functioning of organizations involves more than formal hierarchical structures within them or interorganizational relationships formally governed by contracts. Thus, much of what is decided within or between organizations comes from informal interactions. Thus, network can be understood by a group of actors or social entities that are linked (interrelated) through a set of connections / contacts, achievement is possible to exchange information, resources, or both (BORGATTI; FOSTER, 2003; BORGATTI et al., 2009).

Nodes and ties, where the nodes represent the actors (individuals, organizations) and the ties, the relationships between them, give the composition of a network. For Borgatti, Brass and Halgin (2014), the dyadic ties link up through nodes to form a system of interdependencies, allowing network explanations to be sought not only within actors but also in their network environments. For Borgatti et al. (2009) the ties among actors can be of many different types, such as friendship, competition and can be characterized along multiple dimensions, such as duration, frequency, and the like.

Tomaél and Marteleto (2006) emphasize that social networks refer to people, organizations or other social entities that connect through relationships motivated by friendship (RIENTIES; NOLAN, 2014), work or information sharing. For Lyon (2000), friendships can be calculative and instinctive forms, and that the relationship and the type of reciprocity developed in friendships is considered to be different from a simple working relationship. Thus, in the field of organizational studies, social networks have informality in intercompany relations as a fundamental characteristic, since they do not have any kind of agreements or formal contracts (AMATO NETO, 2008).

For Inojosa (1999) and Schlithler (2004), social networks are products of a process of shared experiences and situations of demands and problems. It is noticed that the isolated equation is not enough, establishing a commitment among its members, to the point of calling such alignments as networks of social commitment. Agents inserted in formal or informal networks can easily develop reciprocity, and thus generate mutual benefits, with the construction of social capital (PUTNAM, 2001). 
For Adler and Kwon (2002), social capital is understood roughly as the goodwill that is engendered by the fabric of social relations, by individuals or groups, and the source lies in the structure and content of actors' social relations. For Coleman (1988), social capital is unlike all other forms of capital once is not found in the actors, but in the relations with other actors, facilitating the actions of individuals within the structure. According to the author, social capital is a resource between families and communities, which introduces a socio structure approach. Putnam (1993) expands the scope of the collectivist approach including in elements of definition, sense of pertain, community cooperation, civic engagement and norms of trust and reciprocity.

For Borgatti and Foter (2003), Colleman and Putnam understand a group's social capital in terms of broad cross-cutting interconnections among all group members. Adler and Kwon (2002) complement that the effects of social capital begin from the information, influence and solidarity provided by the actor.

Putnam (1993) and Adler and Kwon (2002) analyzes the importance of the social capital involved in networks for the good progress of governments and the economy. They point out that network of civic engagement promote robust norms of generalized reciprocity, in the sense that a person can do a favor to someone, in the expectation that the same person, or another, will return a favor. Networks, according Putnam (1993) also tend to facilitate coordination and communication, and amplify information about the reliability of other individuals. Stocks of social capital, such as trust, norms, and networks, tend to be self-reinforcing and cumulative. Successful collaboration in a venture builds connections and trust-social resources that facilitate future collaboration in other unrelated tasks. Like other public goods, from clean air to safe streets, social capital tends to be undervalued by private agents. This means that social capital must often be a by-product of other social activities. Social capital usually consists of bonds, norms and trust transferable from one social environment to another (PUTNAM, 1993). Putnam complements Coleman (1998) who had defined three key components for social capital: trust or the expectation and obligations of informal relations, information channels, and norms with effective sanctions.

For Adler e Kwon (2002) the amplitude of the social capital concept reflects the fact that social ties of one kind (e.g., friendship) can be used for different purposes (e.g., moral and material support, work and nonwork advice), creating what Coleman (1988) call the appropriability of the social structure.

For Putnam (2001) agents insert in formal or informal networks can easily develop reciprocity and thus there can be mutual gains, central idea of social capital, in my view, is that networks and associated norms of reciprocity have value for people insert. Borgatti and Foster (2003, p. 993) go further and assert that "in the most general terms, the concept about social capital is about the value of connections".

For Adler e Kwon (2002) the social capital is sources available for actors according to their location in the structure of their social relations. The authors point out we can distinguish conceptually three dimensions of social structure, one being social relations. In this case, for the authors, gifts and favors exchanged, constitute the dimension of social structure underlying social capital.

For Putnam (2000), two forms of such structural social capital exist: horizontal ties between people with similar characteristics in terms of their shared social identity, also called the bonding social capital (group of farmers within a village); and vertical ties, which would be the ties between groups with different characteristics, comprise relations of respect and mutuality between people who know that they are not alike in some socio-demographic ways. For Carrillo Álvarez and Riera 
Romaní (2017), to discriminate social capital between bonding and bridging allows to classify the links between the members of the group in terms of homogeneity.

For Adler e Kwon (2002), in Putnam and Coleman views, the social capital of a collectivity (organization, community) is not so much in that collectivity's external ties to other external actors, but mainly in its internal structure. Putnam (2001) emphasizes the existence of a very dense, interconnected, multiplex form of social capital (for example, farmers living in the same district, part of the same cooperative and attending the same church and club) as well as very thin, almost invisible forms of social capital (for example, farmers who occasionally meet in the same store of inputs).

\subsection{Social Network Analysis (SNA)}

The purpose of SNA is to study the influence that the relational structure, in which individuals or organizations are embedded, can have on their behavior (MARTELETO, 2001). Some concepts are important to understand the operation of the SNA method. Firstly, two elements are fundamental for a network to exist and for it to be analyzed: actors (nodes) and relations (ties). Knoke and Yang (2008) show that actors in a network can be individuals or organizations (formal or informal).

The network concept emphasizes the fact that each actor has ties to other actors, who may be connected to a few or many actors and so on (WASSERMAN; FAUST, 2009). These authors cite the ties (or types of relationships) that are commonly employed in SNA, among them: a) evaluation of one person for another (when expressing friendship, connection); b) transfer of material resources (business transactions, loan of objects); c) membership association (joint participation in social events, belonging to the same social club); d) behavioral interactions (conversations, messaging); e) physical connection (a road, a river or a bridge connecting two points); f) biological relationship (affinity).

For Borgatti, Brass and Halgin (2014), the structure of a group - the pattern of who is connected to whom- is as consequential for the group as are the characteristics of its members.

SNA produces metrics for both actor analysis and network structure analysis (VALENTE et al, 2008; BISWAS; BISWAS, 2017; ZHAO; ZHAO; CUI, 2017). One of the actors-level metrics (or nodes) is centrality, which, according to Borgatti, Everett and Freeman (2002) and Rossoni and Hocayen-da-Silva (2008), can be classified in degree centrality; closeness centrality; betweenness centrality. Table 1 shows how these measures are defined.

SNA also produces metrics related to the network structure, such as density and centralization of the network (KIM et al., 2011; ZHAO; ZHAO; CUI, 2017). According to Kim et al., (2011) and Ahuja, Soda and Zaheer (2012), the network density refers to the total number of ties in a network in relation to the number of total possibilities of ties that could be formed. While network centralization is related to the distribution of power or control in the network (ZHAO; ZHAO; CUI, 2017). Kim et al. (2011) point out that the network with the greatest possible centralization is the one that presents the star-shaped structure, that is, a single node in the center is connected to all other nodes and these other nodes are not connected to each other.

Likewise, the lowest degree of centralization occurs when all nodes have the same number of connections to each other. Network centralization and density are interconnected measures, so that the smaller the network centralization the greater its density (KIM et al., 2011; ARAOS; VERGARA, 2015). 
Another possible property to be identified in a network is the relational cohesion of the pairs of actors. Understanding cohesion occurs through the intensity of the relationship, such as whether it is strong or weak or whether the relationships are short or long-term (SACOMANO NETO, 2004). The author reflects that although cohesion is related to density, care must be taken not to confuse the terms: while density is a variable relative to the overall structure of the network, cohesion refers to the relationships between the pairs of actors in the network.

Table 1 - Definition of centrality measures

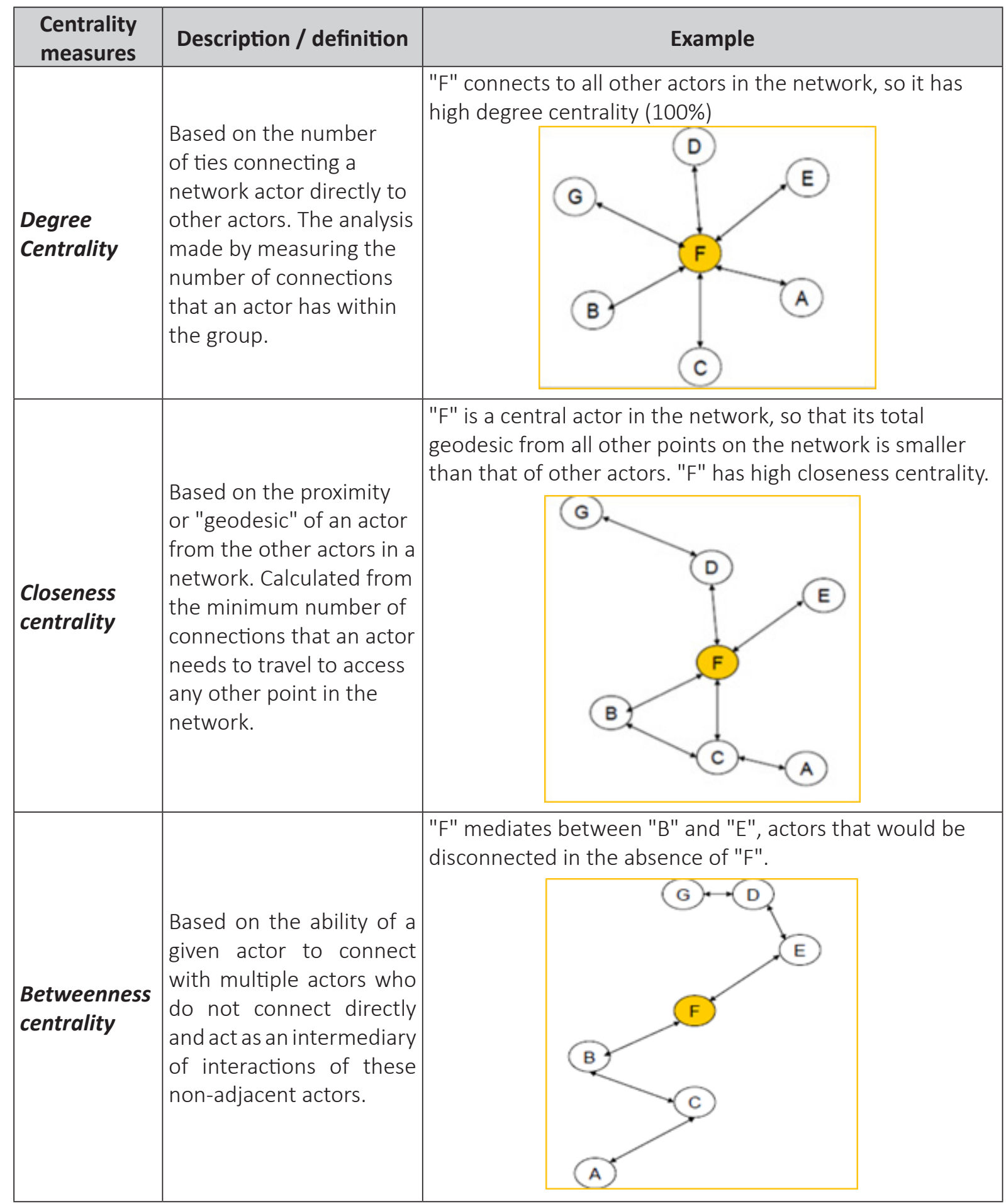

Source: Prepared by the authors from Borgatti, Everett and Freeman (2002), Rossoni and Hocayen-da-Silva (2008) and Giuliani and Pietrobelli (2011). 
Borgatti (2005) and Borgatti, Brass and Halgin (2014) research often conceives of networks as pipes or roads and implicitly or explicitly constructs a model of expected flows through the network. Measures of centrality provide estimates for each of the node, of the times or frequency of arrival, of something flowing through the network, for example, the information.

Hannemann and Hiddle (2005) explain that network surveys are conducted from a population identified and not from a sample, because according to them when we select an actor, they may choose other actors in their relationship who may not be in the sample.

To analyze such configurations, network research methods are proposed, such as: (a) Ego Network: indicated when it aims to collect information from an actor and his peers, without establishing links between these peers; (b) Ego network with connections: provides the selection of focal actors and then the identification of other actors belonging to the network of the first selected. Subsequently, it is determined which actors are connected to each other; (c) Snowball Method: each actor in an initial list indicates a set of other actors with whom they have ties, which form the second list. In turn, the actors included in the second list identify other actors, and so on. This process repeats until no other actors are found or until a deliberate stop of the researcher occurs, due to time, financial resources or because the new actors indicated are very marginal to the group studied; (d) Complete network method: requires the collection of information about the ties of each actor with all other actors, which allows very powerful descriptions and social structures analyzes (GIULIANI; PIETROBELLI, 2011; ARNABOLDI et al., 2017).

The latter is also defined by Thaden and Rotolo (2009), as "Roster" (or "complete list"), where the researchers present to the interviewee a list containing the names of all the actors that compose the network to be analyzed and ask them to identify with whom they have relationships. This method minimizes the risk of data loss due to possible forgetfulness of the respondents since each of them has a complete list of other network actors to consult before answering the questions about relationships (GIULIANI; PIETROBELLI, 2011).

It is important to note that the Roster method can only be used when the set of actors that compose the network is known in advance by the researcher and is more suitable for network researches with a limited number of actors (BUTTS, 2008; THADEN; ROTOLO, 2009).

\section{MATERIALS AND METHODS}

Exploratory methods characterize this research, which has a qualitative approach based on a multi-case study. The instrument used for data collection was the semi-structured questionnaire where the interviewees were tilapia fish farmers in tank-nets inserted at HPP Canoas I reservoir. The questionnaire was validated after the application of a pilot form applied in the presence of one of the reservoir fish farmers.

Considering the characteristics of the population and the objectives of the paper, the research of networks was conducted by the Roster method, as described by Komarudin et al. (2013). The method is appropriate for this research taking into account the limited number of actors in the network and the fact that the researcher has contact with support entities (São Paulo Agribusiness Technology Agency [APTA], s.d., and Paraná Institute of Technical Assistance and Rural Extension [EMATER-PR], s.d.) that made it possible to identify them.

A list containing the names of the 12 actors that make up the network of fish farmers at HPP Canoas I reservoir was elaborated, with four in the state of São Paulo and eight in the state of Paraná. The interviews took place between August and September 2015. 
To analyze the relationship between fish farmers each fish farmer interviewed was asked about the type or degree of relationship he has with other fish farmers installed at HPP Canoas I reservoir, and the possible answers would be: 0) "I have no relationship"; 1) "association member"; 2) "neighborhood"; 3) "friendship"; and 4) "family/ affinity"; generating a proxy from the centrality and density in the network.

Regarding the relationships with inputs suppliers (fingerlings and feed), tilapia buyers and technical advisors, the interviewees were free to quote with whom they relate. Thus, the focus of the study came from the fish farmers who maintain their tank-nets at HPP Canoas I reservoir and extended upstream and downstream to the agents of the production, which may or may not be located in the same region. Information on fingerlings suppliers (FLS), feed suppliers (FS), tilapia buyers (TB) and advisors (ADV) come from the views and opinions of the interviewed fish farmers, who were the only ones interviewed. They were asked about people and companies from whom they buy fingerlings and feed, to whom they sell their produce and to whom they turn in case of technical or management doubts. From the fish farmers responses to the block of relational questions, tables and matrices were created in order to begin the mapping of networks with the software UCINET', version 6 (BORGATTI; EVERETT; FREEMAN, 2002).

It was decided not to question the interviewees directly about trust in the relationships between fish farmers. Instead, it was adopted that trust would be given by the sum of frequency, time and value attributed to the information exchanged.

The degrees of the centrality of each fish farmer was used for frequency, time and value. The trust was calculated from a heuristic, based on Born and Frey (2017), Vie et al. (2017), and Quiñones and Rusu (2017) from the arithmetic average (without weighting) of these values, as shown by the equation:

$$
f(t r)=\frac{(f)+(t)+(v)}{3}
$$

Where,

$f(t r)=$ trust function

$f \quad=$ relationship frequency

$t=$ relationship time

$v \quad=$ value attributed to the relationship

\section{RESULTS AND DISCUSSION}

For a better understanding of the results on the networks where the fish farmers are inserted, they will be presented in two sections, the first being the network relationships between fish farmers and the second the network relationships between fish farmers and other agents of the chain.

\subsection{Relationship between fish farmers}

Each fish farmer interviewed was asked about the type or degree of relationships he has with other fish farmers installed at HPP Canoas I reservoir, and the information obtained through the form was treated and mapped, as can be seen in Figure 1 and Table 2. 
Figure 1 - Relationship map between fish farmers

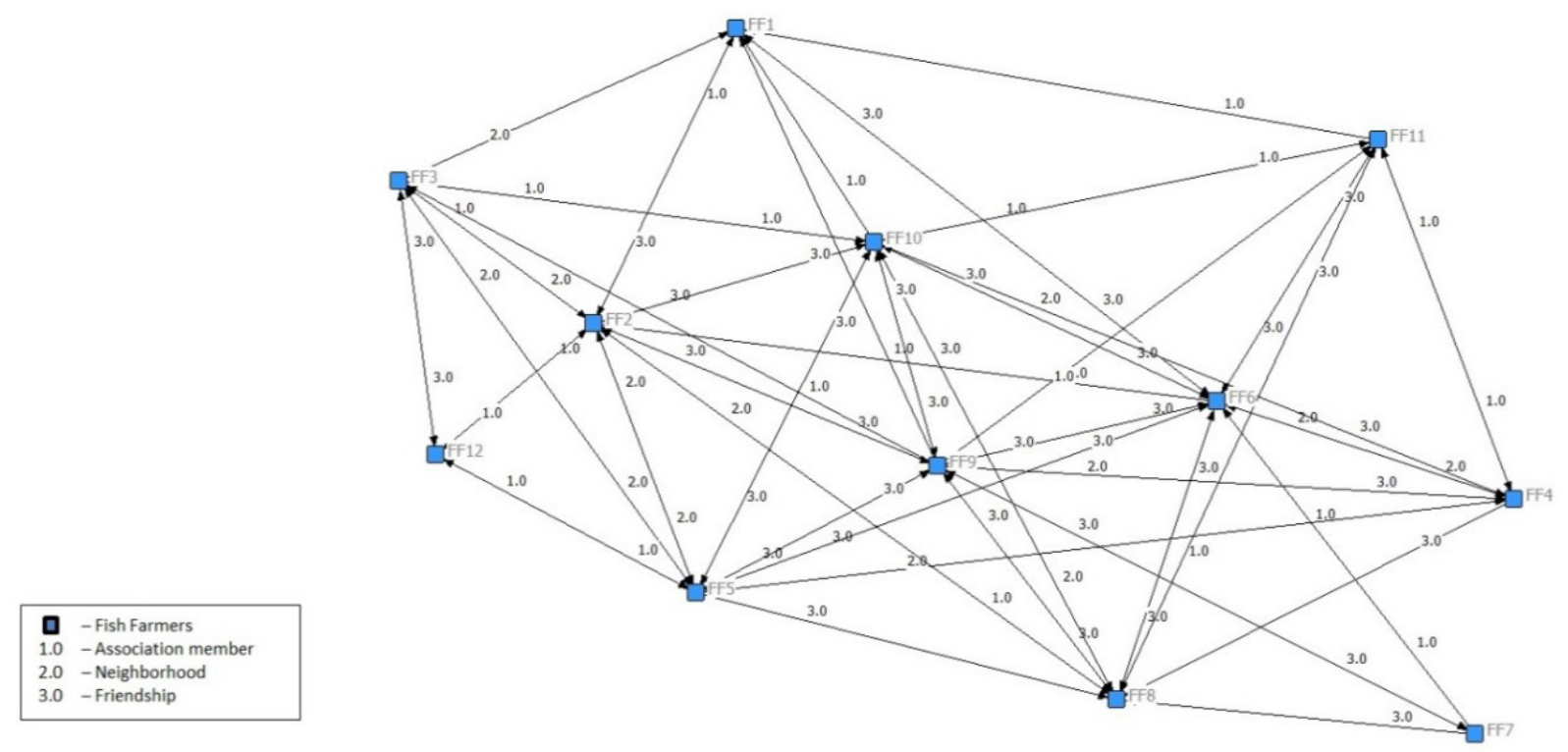

Source: Prepared by the authors using the UCINET ${ }^{\circledR}$ Software.

The network relationships between fish farmers, given by a square matrix $12 \times 12$ (twelve respondents), following the foundation of Grandori and Soda (1995), is a social network dictated by neighborhood ties and friendship. Deepening into the theory of Brand and Verschoore (2014), it is characterized as an asymmetric social network when different actors have different levels of power (or centrality). It is also a network in which the pairs of actors have high cohesion (strong ties relationships) and, therefore, tends to a dense network (a large number of connections and strong connections), but with structural holes, since not all fish farmers relate to each other.

The relationship degree 4 (family/ affinity) was not mentioned by any fish farmer, so the highest relational degree found in the network is the friendship relation (degree 3). When analyzing the relationships between farmers, traders and agricultural input suppliers, Lyon (2000) shows the value of friendship in the social network.

As shown in Table 2, FF6, FF9, and FF10, followed by FF5, had the highest degree centrality. This centrality was obtained by dividing the number of existing relationships (for each fish farmer) by the number of possible relationships, which, in this case, are 11. According to Wasserman and Faust (2009), Scott (2017) and Durmuşoğlu (2013), FF6, FF9 and FF10 have greater visibility and are in direct or adjacent contact with other actors. These actors are essential agents in the process of searching and implementing the of knowledge transfer and information sharing. In addition, play an important role of coordination in the group.

The FF6, FF9, and FF10 fish farmers have all the connections and enjoy high degree relationships (friendship) which contributes to greater centrality and prominence in the network, as stated by Zhao, Zhao and Cui (2017). This result also corroborates Adler and Kwon (2002) and Borgatti (2009) who emphasize friendship as an important form of social capital in the formation and strengthening of social relationship

The other fish farmers have a lower degree centrality than those mentioned, with FF1 having the lowest degree centrality, with only 5 out of 11 possible links. This may be due to its short operation time exploring the activity (less than a year). 
Table 2 - Centrality measures: relationship between fish farmers

\begin{tabular}{|c|c|c|c|}
\hline & Degree & Closeness & Betweenness \\
\hline FF1 & 45.455 & 64.706 & 0.000 \\
\hline FF2 & 72.727 & 78.571 & 1.909 \\
\hline FF3 & 63.636 & 73.333 & 0.727 \\
\hline FF4 & 63.636 & 73.333 & 0.303 \\
\hline FF5 & 81.818 & 84.615 & 3.273 \\
\hline FF6 & 100.000 & 100.000 & 8.242 \\
\hline FF7 & 54.545 & 68.750 & 0.000 \\
\hline FF8 & 72.727 & 78.571 & 1.485 \\
\hline FF9 & 100.000 & 100.000 & 8.242 \\
\hline FF10 & 100.000 & 100.000 & 8.242 \\
\hline FF11 & 63.636 & 73.333 & 0.303 \\
\hline FF12 & 54.545 & 68.750 & 0.000 \\
\hline
\end{tabular}

Source: Prepared by the authors using the $\mathrm{UCINET}^{\circledR}$ software

The FF6, FF9, FF10 and FF5 fish farmers have high values for closeness centrality because they do not have to go through many other ties to reach other points in the network. In addition, they behave as intermediating agents, causing other non-adjacent fish farmers to be linked, even indirectly. Consequently, they present the highest values of betweenness centrality.

It is interesting to note that the most evident fish farmers in the network, FF6, FF9, and FF10, are located in Paraná's side of the reservoir and have been in the tilapia production area in the region for a long time (more than ten years). This fact contributes to the high recognition by the others and in the development of intense relations throughout the years.

In addition, FF6, FF9, FF10, and FF5 are members of fish farmers associations, which gives them greater visibility, besides being involved in discussions about the activity. Participating in the association, in addition to the proximity of the place of residence (all located in Paraná) brings these producers to the more dense form of social capital proposed by Putnam (2001).

An interesting observation is that the fish farmers of São Paulo have more strong ties relationships with the fish farmers of Paraná than with each other. This can be inferred from the fact that São Paulo fish farmers act shorter in this activity. They look for the most experienced fish farmers (Paraná fish farmers) to help with their doubts (mainly of a technical nature) instead of turning to the neighborhood fish farmers who are also young, both in age and in time in the activity.

Fish farmers were also asked about the frequency of information exchange with each other and the value of this. The fish farmers assigned frequency notes for information exchange with the other fish farmers inserted at HPP Canoas I and also the value of this information exchanged, as represented: "Low value information" (information that does not cause productive and economic impact); "Moderate value information"; and "information of great strategic value" (information that allows significant improvements in productive and economic level).

Related to the frequency of information exchange, FF6, FF9, and FF10 are the ones that provide information that is more constant to other fish farmers, in their own view. Other fish farmers when asked who receives information more frequently endorse this attribute. This characteristic was expected since, in terms of the frequency of information exchange, fish farmers have similar perceptions. 
Regarding the value attributed to the information received from each fish farmer, P9 is more centralized on the network, so those who receive it consider the information he disseminates of high strategic value. FF6 and FF10 are also important fish farmers because of the value of the information they give to others. The value attributed to the information received from these fish farmers has more relation with the time and experience (more than 10 years) that they have in the activity than with the schooling and age group. The fact that FF6, FF9, and FF10 are part of fish farmers associations and frequently participate in discussions about the activity may confer greater value to the information passed on by them.

\subsection{Trust between fish farmers}

Trust is an important attribute of social networks, since many of the decisions made by actors in a network can be based on what they know about other actors and, consequently, their trust or distrust on them (RAJ; BADU, 2017; BO et al., 2017; XIONG; LIU; CHENG, 2017).

Table 3 - Level of trust attributed to each farmer based on frequency, time and value of information exchanged

\begin{tabular}{|c|c|c|c|c|}
\hline & Frequency & Time & Value & Trust \\
\hline FF9 & $90,90 \%$ & $90,90 \%$ & $90,90 \%$ & $90,90 \%$ \\
\hline FF6 & $81,81 \%$ & $81,81 \%$ & $81,81 \%$ & $81,81 \%$ \\
\hline FF10 & $81,81 \%$ & $81,81 \%$ & $81,81 \%$ & $81,81 \%$ \\
\hline FF2 & $72,72 \%$ & $72,72 \%$ & $72,72 \%$ & $72,72 \%$ \\
\hline FF5 & $72,72 \%$ & $72,72 \%$ & $72,72 \%$ & $72,72 \%$ \\
\hline FF8 & $72,72 \%$ & $72,72 \%$ & $72,72 \%$ & $72,72 \%$ \\
\hline FF3 & $54,54 \%$ & $54,54 \%$ & $54,54 \%$ & $54,54 \%$ \\
\hline FF4 & $54,54 \%$ & $54,54 \%$ & $54,54 \%$ & $54,54 \%$ \\
\hline FF1 & $54,54 \%$ & $45,45 \%$ & $45,45 \%$ & $48,48 \%$ \\
\hline FF11 & $54,54 \%$ & $45,45 \%$ & $45,45 \%$ & $48,48 \%$ \\
\hline FF7 & $27,27 \%$ & $27,27 \%$ & $27,27 \%$ & $27,27 \%$ \\
\hline FF12 & $27,27 \%$ & $27,27 \%$ & $27,27 \%$ & $27,27 \%$ \\
\hline
\end{tabular}

Source: Prepared by the authors.

The values obtained for trust for each of the fish farmers can be checked in Table 3 in descending order (higher trust level to lower trust level).

Corroborating with the previous results, the FF6, FF9 and FF10 fish farmers obtained a higher level of trust, taking into account the high frequency that they exchange information with other fish farmers, the time-space in which they exchange them and the value that the information passed by them has for other fish farmers.

On the other hand, three fish farmers from São Paulo (FF1, FF3, and FF12) had a relatively low trust level, $48.48 \%, 54.54 \%$ and $27.27 \%$, respectively. This is due to the lower frequency, time and value of the information exchanged by these fish farmers. The explanation is in the shorter time of these individuals in tank-net fish farming activity, as well as in the lower articulation observed among the fish farmers from São Paulo than among the ones from Paraná. 


\subsection{Relationships between fish farmers, fingerlings and feed suppliers, buyers and advisors: extended network}

The fish farmers were asked about people and companies from whom they buy fingerlings and feed, to whom they sell their produce and to whom they turn in case of technical or administrative doubts.

Figure 2 shows the complete network of relationships, i.e., fish farmers and other agents.

Figure 2 - Enlarged network map

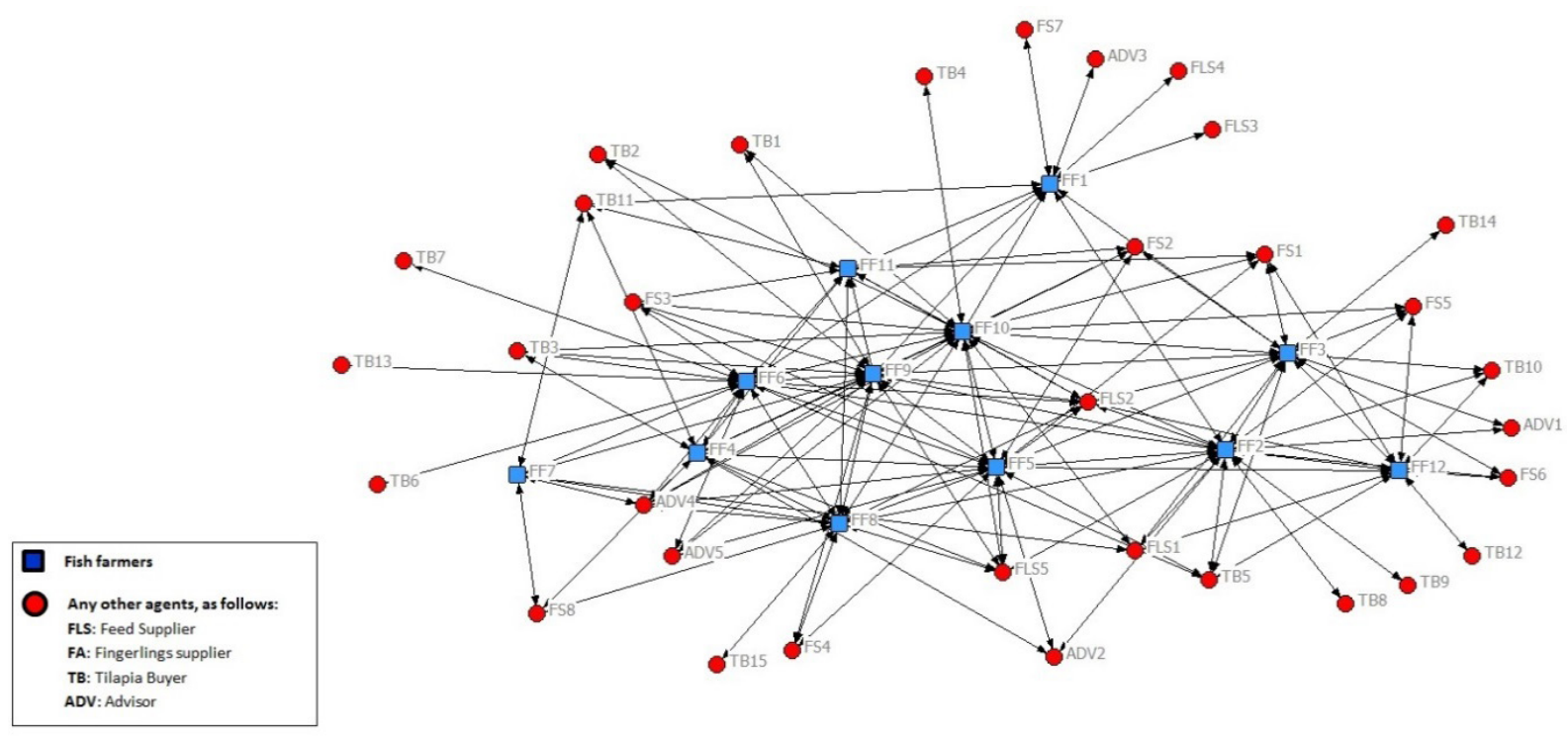

Source: Prepared by the authors using the UCINET ${ }^{\circ}$ software

The enlarged network is also an asymmetric social network, since it does not have formal contracts with suppliers and buyers, and the actors do not have equal levels of centrality. However, unlike the fish farmer network, the expanded network has besides fish farmers, upstream and downstream producers (fingerlings and feed suppliers, buyers and advisors) linked by weak ties.

It is important to remember that, according to Granovetter (1973), although they are called "weak ties", they are as important as strong ties in the relational structure of the network. This can be explained in case of non-routine situations. For example, in the case of the occurrence of a disease affecting the reservoir and consequently all fish, the information exchange condition is faster in the network formed by strong ties. However, information and potential solutions are not under its control, but in the network of weak ties (extended network).

Based on the relationship between fish farmers and expanding to the network that includes fingerlings and feed suppliers, buyers and advisors, it is possible to verify that FF5, FF6, FF9, and FF10 also play important roles.

The absence of FF5 and FF9 in the network would leave buyers, suppliers, and advisors with fewer connections, but not isolated. The importance of these agents (suppliers, buyers, and assessors) in the analyzed network would be reduced, since P5 and P9 are fish farmers with average production considered high, buying inputs and selling tilapia with high frequency and quantity.

On the other hand, buyers such as TB4 (attached to FF10) and TB6, TB7 and TB13 (attached to FF6) would be completely isolated if FF6 and FF10 were absent from the network. Although FF6 
exploits the activity in Paraná, TB6, TB7, and TB13 are in the state of São Paulo in municipalities more distant from the reservoir. The distance and the fact that they only have a connection with FF6 in the network in question may indicate that they buy from this fish farmer for relational reasons (friendship and trust) and not for logistical feasibility or only economic results.

For the analyzed network, the buyer market is pulverized, being formed by intermediaries, refrigerators, fish-pay and food establishments. Fingerlings (FA) and feed suppliers (FR) are part of a concentrated market characterized by the high scale of production, technology, and knowledge required. Consequently, certain tilapia buyers have less force in the network, being more dependent on fish farmers (less bargaining power) than fingerlings and fish suppliers are.

Regarding the relationships with agents upstream of tilapia production, as fingerlings and feed suppliers, the factors presented by the fish farmers were product quality, trust in the supplier and price paid for the product (cost-benefit).

In the case of the relationship with advisory agents, three fish farmers (one from Paraná and two from São Paulo) reported not to resort to anyone specialized in cases of administrative doubts. The other fish farmers mentioned the EMATER (one), the members' council (five), the father (two) ${ }^{4}$ and other fish farmers (one). On technical issues, most (eight fish farmers) mentioned turning to fingerlings, feed, and vaccines suppliers, which have some type of academic training as veterinary medicine, animal husbandry, and others. In the case of Paraná's fish farmers, five of them also resort to the advice provided by EMATER, while São Paulo's fish farmers reported not receiving orientations from institutions. Two of them mentioned seeking information on courses and fairs related to the fish farming activity.

\section{CONCLUSIONS}

The objective of the present paper was to analyze the insertion in social networks of agents producing tilapia in tank-nets. For this, a group of fish farmers installed at HPP Canoas I reservoir was interviewed, sheltering twelve tilapia producers in tank-nets.

It was possible to perceive that the most inserted fish farmers in the network are those that the other fish farmers consider transmitting information of greater value. They were experienced in the activity, working with aquaculture in tank-nets for a long time. Since schooling and age range differ among them, this seems to be the most influential factor to highlight these fish farmers in the analyzed social network.

The same three fish farmers identified are also cited as the main transmitters of information within the network. The experience of these actors, in relation to the others, and the participation in associations contribute to their prominence. The search for information with the other members of the network, to the detriment of technicians, reinforces the positioning of friendship as the greatest relational degree found in the network.

The trust degree in relationships among fish farmers measured indirectly from the frequency, time and value attributed to the information exchanged, corroborated the previous analyzes, showing that the agents who transmit more information and of greater value are the same three fish farmers mentioned as more central in the network.

It was also possible to verify that the other agents of tilapia production, with which fish farmers have relationships, have different characteristics. While fingerlings and feed suppliers are

\footnotetext{
${ }^{4}$ The fathers who acted as consultants, although fish farmers, are not in the network
} 
concentrated due to the high scale of production, technology, and knowledge to be invested, the buyer's market for tilapia is sprayed. The factors presented by fish farmers for the relationships with the agents upstream chain were product quality, trust in the supplier and price paid for the product (cost-benefit).

For future studies, it is recommended to analyze in a deeper way the benefits that the insertion in networks brings to the fish farmers, identifying, for example, if the higher level of insertion in the network allows economic gains due to greater bargaining power with inputs suppliers and tilapia buyers.

\section{REFERENCES}

ABRAMOVAY, R. O capital social dos territórios: repensando o desenvolvimento rural. Economia Aplicada, v. 4, n. 2, p. 379-97, Apr./June 2000.

ADLER, P. S.; KWON, S. W. Social capital: prospects for a new concept. Academy of Management Review, v. 27, n. 1, p. 17-40, 2002. DOI: https://journals.aom.org/doi/10.5465/amr.2002.5922314

AHUJA, G. Collaboration networks, structural holes, and innovation: a longitudinal study. Administrative Science Quarterly, v. 45, n. 3, p. 425-55, Sep. 2000. DOI: https://doi.org/10.2307/2667105

AHUJA, G.; SODA, G.; ZAHEER, A. The genesis and dynamics of organizational networks. Organization Science, v. 23, n. 2, p. 434-48, Mar./Apr. 2012. DOI: https://doi.org/10.1287/orsc.1110.0695

AMATO NETO, J. Redes de cooperação produtiva e clusters regionais: oportunidade para pequenas e médias empresas. São Paulo: Atlas, 2008.

APTA. Agência Paulista de Tecnologia dos Agronegócios. [s.d.]. Available in: http://www.apta.sp.gov.br/\#. Access in: 12 May 2015.

ARAOS, K. B.; VERGARA, M. L. Relación entre confianza, cooperación y redes sociales Evidencia experimental en Chile. REDES-Revista hispana para el análisis de redes sociales, v. 26, n. 2, p. 118-57, Dec. 2015. DOI: https://doi.org/10.5565/rev/redes.537

ARNABOLDI, V.; CONTI, M.; PASSARELLA, A.; DUNBAR, R. I. Online Social Networks and information diffusion: the role of ego networks. Online Social Networks and Media, v. 1, p. 44-55, June 2017. DOI: https://doi. org/10.1016/j.osnem.2017.04.001

AYROZA, L. M. S. Criação de tilápia-do-nilo, Oreochromis niloticus, em tanques-rede na Usina Hidrelétrica de Chavantes, Rio Paranapanema, SP/PR. 2009. 92f. Advisor: Elizabeth Romagosa. Thesis (Doctorate in Aquicultura) - Centro de Aquicultura, Universidade Estadual Paulista "Júlio de Mesquita Filho", Jaboticabal, SP, 2009. Available in: https://repositorio.unesp.br/handle/11449/100248. Access in: 20 Feb. 2015.

AYROZA, L. S. M.; AYROZA, D. M. M. R. Panorama da piscicultura no estado de São Paulo. Pesquisa e Tecnologia, São Paulo, v. 9, n. 2, p. 1-6, July/Dec. 2012. Available in: http://www.aptaregional.agricultura. sp.gov.br/acesse-os-artigos-pesquisa-e-tecnologia/edicao-2012/julho-dezembro-2/1227-panorama-dapiscicultura-no-estado-de-sao-paulo/file.html?force_download=1

AYROZA, L. M. S.; FURLANETTO, F. P. B.; AYROZA, D. M. M. R.; SUSSEL, F. R. Piscicultura no Médio Paranapanema: situação e perspectivas. Pesquisa e Tecnologia, São Paulo, v. 2, n. 2, p. 1-8, July/Dec. 2005. Available in: http://www.aptaregional.sp.gov.br/acesse-os-artigos-pesquisa-e-tecnologia/edicao2005/2005-julho-dezembro/152-piscicultura-no-medio-paranapanema-situacoes-e-perspectivas/file. html?force_download $=1$ 
BISWAS, A.; BISWAS, B Defining quality metrics for graph clustering evaluation. Expert Systems with Applications, v. 71, p. 1-17, Apr. 2017. DOI: https://doi.org/10.1016/j.eswa.2016.11.011

BO, Z.; HUAN, Z.; MEIZI, L.; QIN, Z.; JIFENG, H. Trust traversal: a trust link detection scheme in social network. Computer Networks, v. 120, p. 105-25, June 2017. DOI: https://doi.org/10.1016/j.comnet.2017.04.016

BORGATTI, S. P. Centrality and network flow. Social Networks, v. 27, n. 1, p. 55-71, Jan. 2005. DOI: https:// doi.org/10.1016/j.socnet.2004.11.008

BORGATTI, S. P.; EVERETT, M. G.; FREEMAN, L. C. Ucinet for Windows: software for social network analysis. Harvard, MA: Analytic Technologies, 2002.

BORGATTI, S. P.; BRASS, D. J.; HALGIN, D. S. Social network research: confusions, criticisms, and controversies. In: BRASS, D. J.; LABIANCA, G.; MEHRA, A.; HALGIN, D. S.; BORGATTI, S. P. (Ed.). Contemporary perspectives on organizational social networks. Bingley, Reino Unido: Emerald Group Publishing Limited, 2014. p. 1-29.

BORGATTI, S. P.; MEHRA, A.; BRASS, D. J.; LABIANCA, G. Network Analysis in the Social Sciences. Science, v. 323, n. 5916, p. 892-5, Feb. 2009. DOI: https://doi.org/10.1126/science.1165821

BORGATTI, S. P.; FOSTER, P. C. The network paradigm in organizational research: a review and typology. Journal of Management, v. 29, n. 6, p. 991-1013, Dec. 2003. DOI: https://doi.org/10.1016/S01492063(03)00087-4

BORN, S.; FREY, A. Heuristic constraint management methods in multidimensional adaptive testing. Educational and Psychological Measurement, v. 77, n. 2, p. 241-62, 2017 DOI: https://doi. org/10.1177/0013164416643744

BRAND, F. C.; VERSCHOORE, J. R. A utilização de medidas de análise de redes sociais nas pesquisas em administração. Revista Economia \& Gestão, Belo Horizonte, v. 14, n. 35, p. 212-37, Apr./June 2014. Available in: http://200.229.32.55/index.php/economiaegestao/article/view/P.1984-6606.2014v14n35p212. Access in: 20 Feb. 2015.

BRASIL. Consumo de pescado no Brasil aumenta 23,7\% em dois anos. 2013. Available in: http://www. brasil.gov.br/economia-e-emprego/2013/10/consumo-de-pescado-no-brasil-aumenta-23-7-em-doisanos. Access in: 9 June 2014.

BRASIL. Boletim estatístico da pesca e aquicultura - Brasil. 2011. Available in: http://www.icmbio.gov.br/ cepsul/images/stories/biblioteca/download/estatistica/est_2011_bol_bra.pdf. Access in: 28 May 2014.

BUTTS, C. T. Social network analysis: a methodological introduction. Asian Journal of Social Psychology, v. 11, n. 1, p. 13-41, Mar. 2008. DOI: https://doi.org/10.1111/j.1467-839X.2007.00241.x

CARRILLO ÁLVAREZ, E.; RIERA ROMANÍ, J. Measuring social capital: further insights. Gaceta Sanitaria, v. 31, n. 1, p. 57-61, Jan./Feb. 2017 DOI: https://doi.org/10.1016/j.gaceta.2016.09.002

COLEMAN, J. S. Social capital in the creation of human capital. American Journal of Sociology, v. 94, suppl., p. S95-S120, 1988. Available in: https://www.jstor.org/stable/2780243?seq=1\#metadata_info_tab_contents

CREPALDI, D. V.; FARIA, P. M. C.; TEIXEIRA, E. A.; RIBEIRO, L. P.; COSTA, A. A. P.; MELO, D. C.; CINTRA, A. P. R.; PRADO, S. A.; COSTA, F. A. A.; DRUMOND, M. L.; LOPES, V. E.; MORAES, V. E. A situação da Aquacultura e da pesca no Brasil e no mundo. Revista Brasileira Reprodução Animal, Belo Horizonte, v. 30, n. 3/4, p. 81-5, July/Dec. 2006. Available in: http://cbra.org.br/portal/publicacoes/rbra/2006/rbrajd2006. html. Access in: 28 May 2014. 
CURY, A. Organização e métodos: uma visão holística. 8. ed. São Paulo: Atlas, 2012.

DURMUŞOĞLU, S. S. Merits of task advice during new product development: network centrality antecedents and new product outcomes of knowledge richness and knowledge quality. Journal of Product Innovation Management, v. 30, n. 3, p. 487-99, May 2013. DOI: https://doi.org/10.1111/jpim.12002

DAFT, R. L. Organizações: teoria e projetos. 2. ed. São Paulo: Cengage Learning, 2008.

EMATER. Instituto Paranaense de Assistência Técnica e Extensão Rural. [s.d.]. Available in: http://www. emater.pr.gov.br. Access in: 28 May 2015.

FAO. The state of the world fisheries and aquaculture 2016: contributing to food security and nutrition for all. Roma: FAO - Fisheries and Aquaculture Department, 2016. Available in: http://www.fao.org/3/ai5555e.pdf. Access in: 30 Jan. 2017.

GIULIANI, E.; PIETROBELLI, C. Social network analysis methodologies for the evaluation of cluster development programs. Inter-American Development Bank-Technical notes, 2011. Available in: https:// publications.iadb.org/handle/11319/5342. Access in: 28 July 2015.

GODFREY, M. M.; MELIN, C. N. Clinical microsystems, Part 3. Transformation of two hospitals using microsystem, mesosystem, and macrosystem strategies. The Joint Commission Journal on Quality and Safety, v. 34, n. 10, p. 591-603, Oct. 2008. DOI: https://doi.org/10.1016/S1553-7250(08)34074-4. Access in: 10 Mar. 2016.

GRANDORI, A.; SODA, G. Inter-firm networks: antecedents, mechanisms and forms. Organization studies, v. 16, n. 2, p. 183-214, 1995. DOI: https://doi.org/10.1177/017084069501600201

GRANOVETTER, M. Economic action and social structure: the problem of embeddedness. American Journal of Sociology, v. 91, n. 3, p. 481-510, Nov. 1985. DOI: https://doi.org/10.1086/228311

GRANOVETTER, M. The strength of weak ties. The American Journal of Sociology, Chicago, v. 78, n. 6, p. 1360-80, May 1973. DOI: https://doi.org/10.1086/225469

HANNEMAN, R. A.; RIDDLE, M. Introduction to social networks methods. Riverside: University of California, 2005. Available in: http://faculty.ucr.edu/ hanneman/nettext/C1_Social_Network_Data.html. Access in:28 May 2015.

INOJOSA, R. M. Redes de compromisso social. Revista de Administração Pública, Rio de Janeiro, v. 33, n. 5, p. 115-41, Sept./Oct. 1999. Available in: http://bibliotecadigital.fgv.br/ojs/index.php/rap/article/view/7628

JOHNY, J.; WICHMANN, B.; SWALLOW, B. M. Characterizing social networks and their effects on income diversification in rural Kerala, India. World Development, v. 94, p. 375-92, June 2017. DOI: https://doi. org/10.1016/j.worlddev.2017.02.002

KENIS, P.; OERLEMANS, L. The social network perspective: understanding the structure of cooperation. In: CROOPER, S.; EBERS, M.; HUXHAM, C.; SMITH RING, P. Inter-organizational relations. New York: Oxford University Press, 2008.

KIM, Y.; CHOI, T. Y.; YAN, T.; DOOLEY, K. Structural investigation of supply networks: a social network analysis approach. Journal of Operations Management, v. 29, n. 3, p. 194-211, Mar. 2011. DOI: https:// doi.org/10.1016/j.jom.2010.11.001

KOMARUDIN; GUERRY, M. A.; FEYTER, T.; BERGHE, G. V. The roster quality staffing problem - a methodology for improving the roster quality by modifying the personnel structure. European Journal of Operational Research, v. 230, n. 3, p. 551-62, Nov. 2013. DOI: https://doi.org/10.1016/j.ejor.2013.05.009 
KNOKE, D.; YANG, S. Social Network Analysis. London: Sage Publications, 2008.

KUBITZA, F. Aquicultura no Brasil: principais espécies, áreas de cultivo, rações, fatores limitantes e desafios. Panorama da Aquicultura, Rio de Janeiro, v. 25, n. 150, p. 10-23, 2015.

LYON, F. Trust, networks and norms: the creation of social capital in agricultural economies in Ghana. World Development, v. 28, n. 4, p. 663-81, Apr. 2000. DOI: https://doi.org/10.1016/S0305-750X(99)00146-1

MAERTENS, A.; BARRETT, C. B. Measuring social networks' effects on agricultural technology adoption. American Journal of Agricultural Economics, v. 95, n. 2, p. 353-9, Jan. 2013. DOI: https://doi.org/10.1093/ajae/aas049

MARTELETO, R. M. Análise de redes sociais - aplicação nos estudos de transferência da informação. Ciência da Informação, Brasília, v. 30, n. 1, p. 71-81, Jan./Apr. 2001. Available in: http://www.scielo.br/ pdf/ci/v30n1/a09v30n1. Access in: 28 May 2015.

MONAGHAN, S.; LAVELLE, J.; GUNNIGLE, P. Mapping networks: exploring the utility of social network analysis in management research and practice. Journal of Business Research, v. 76, p. 136-44, Apr. 2017. DOI: https://doi.org/10.1016/j.jbusres.2017.03.020

MORGAN, G. Imagens da organização. São Paulo: Atlas, 1996.

NEIVA, E. R.; BRITO, M. J. P. Redes sociais e mudança em uma associação de produtores rurais. Revista Psicologia Organizações e Trabalho, Florianópolis, v. 8, n. 1, p. 5-24, June 2008. Available in: http://pepsic. bvsalud.org/scielo.php?script=sci_arttext\&pid=S1984-66572008000100002. Access in: 28 May 2015.

PUTNAM, R. D. Social capital: measurement and consequences. Isuma: Canadian Journal of Policy Research, v. 2, p. 41-51, 2001.

PUTNAM, R. D. Bowling alone: America's declining social capital. In: CROTHERS, L.; LOCKHART, C. (Ed.). Culture and politics. New York: Palgrave Macmillan, 2000. p. 223-34.

PUTNAM, R. D. The prosperous community: social capital and public life. The American Prospect, v. 13, p. 35-42, 1993. Available in: https://prospect.org/article/prosperous-community-social-capital-and-public-life

QUIÑONES, D.; RUSU, C. How to develop usability heuristics: a systematic literature review. Computer Standards \& Interfaces, v. 53, p. 89-122, Aug. 2017. DOI: https://doi.org/10.1016/j.csi.2017.03.009

RAJ, E. D.; BABU, L. D. An enhanced trust prediction strategy for online social networks using probabilistic reputation features. Neurocomputing, v. 219, p. 412-21, Jan. 2017. DOI: https://doi.org/10.1016/j. neucom.2016.09.036

RIENTIES, B.; NOLAN, E. M. Understanding friendship and learning networks of international and host students using longitudinal Social Network Analysis. International Journal of Intercultural Relations, v. 41, p. 165-80, July 2014. DOI: https://doi.org/10.1016/j.ijintrel.2013.12.003

RIVERA, M. T.; SODERSTROM, S. B.; UZZI, B. Dynamics of dyads in social networks: assortative, relational, and proximity mechanisms. Annual Review of Sociology, v. 36, p. 91-115, 2010. DOI: https://doi.org/10.1146/ annurev.soc.34.040507.134743

ROSSONI, L.; HOCAYEN-DA-SILVA, A. J. Cooperação entre pesquisadores da área de administração da informação: evidências estruturais de fragmentação das relações no campo científico. Revista de Administração-RAUSP, São Paulo, v. 43, n. 2, p. 138-51, Apr./June 2008. Available in: http://www.redalyc. org/pdf/2234/223417512002.pdf. Access in: 28 May 2015. 
RZEPKA, A. Inter-organizational relations as one of sources of competitive advantage of contemporary enterprises in the era of globalization. Procedia Engineering, v. 174, p. 161-70, 2017. DOI: https://doi. org/10.1016/j.proeng.2017.01.195

SACOMANO NETO, M. Morfologia, propriedades e posicionamentos das redes: contribuições às análises interfirmas. In: SIMPÓSIO DE ENGENHARIA DE PRODUÇÃO- SIMPEP, 11., 2004, Bauru, SP. Proceedings [...]. Bauru, SP: UNESP, 2004.

SAMPAIO, J. M. C.; BRAGA, L. G. T. Cultivo de tilápia em tanques-rede na Barragem do Ribeirão de Saloméa - Floresta Azul- Bahia. Revista Brasileira de Saúde e Produção Animal, Salvador, BA, v. 6, n. 2, p. 42-52, 2006. Available in: http://www.rbspa.ufba.br/index.php/rbspa/article/viewArticle/635. Access in: 10 Mar. 2016.

SANDOVAL JÚNIOR, P.; TROMBETA, T. D.; MATTOS, B. O.; SALLUM, W. B.; SORANNA, M. R. G. S. Manual de criação de peixes em tanques-rede. 2. ed. Brasília: Codevasf, 2013.

SCHLITHLER, C. R. B. Redes de desenvolvimento comunitário: iniciativas para a transformação social. São Paulo: Global, 2004.

SCOTT, J. Social Network Analysis: a handbook. London: Sage Publications, 2017.

THADEN, L. L.; ROTOLO, T. The measurement of Social Networks: a comparison of alter-centered and relationship-centered survey designs. Connections, v. 29, n. 1, p. 15-25, 2009. Available in: http://citeseerx. ist.psu.edu/viewdoc/download?doi=10.1.1.211.4342\&rep=rep1\&type=pdf . Access in: 10 Apr. 2016.

TOMAÉL, M. I.; MARTELETO, R. M. Redes sociais: posições dos atores no fluxo da informação. Revista Eletrônica de Biblioteconomia e Ciência da Informação, Florianópolis, n. esp., p. 75-91, 2006. DOI: http:// dx.doi.org/10.5007/1518-2924.2006v11nesp1p75

VALENTE, T. W.; CORONGES, K.; LAKON, C.; COSTENBADER, E. How correlated are network centrality measures? Connections, Toronto, v. 28, n. 1, p. 16-26, Jan. 2008. Available in: https://www.ncbi.nlm.nih. gov/pmc/articles/PMC2875682/. Access in: 10 Apr. 2016.

VIE, J. J.; POPINEAU, F.; TORT, F.; MARTEAU, B.; DENOS, N. A Heuristic method for large-scale cognitivediagnostic computerized adaptive testing. In: ACM CONFERENCE ON LEARNING@ SCALE, 4., April 20-21, 2017, Cambridge, MA, USA. Proceedings [...]. Cambridge, MA, USA, 2017. p. 323-6, DOI: https://doi. org/10.1145/3051457.3054015

WASSERMAN, S.; FAUST, K. Social Network Analysis: methods and applications. New York: Cambridge University Press, 2009.

XIONG, F.; LIU, Y.; CHENG, J. Modeling and predicting opinion formation with trust propagation in online social networks. Communications in Nonlinear Science and Numerical Simulation, v. 44, p. 513-24, Mar. 2017. DOI: https://doi.org/10.1016/j.cnsns.2016.09.015

XIONG, H.; WANG, P.; ZHU, Y. Diffusion on social networks: survey data from rural villages in central China. Data in Brief, v. 7, p. 546-50, June 2016. DOI: https://doi.org/10.1016/j.dib.2016.02.081

ZHAO, S.; ZHAO, P.; CUI, Y. A network centrality measure framework for analyzing urban traffic flow: A case study of Wuhan, China. Physica A: Statistical Mechanics and its Applications, v. 478, p. 143-57, July 2017. DOI: https://doi.org/10.1016/j.physa.2017.02.069 


\section{Sobre os autores:}

Raiane Real Martinelli - Degree in Zootechny (Universidade Estadual de Maringá [UEM], Brasil), Master in Agribusiness and Development (PGAD) (Univ Estadual Paulista [UNESP], Brasil). Doctor student in Zootechny (UEM, Brasil). Research interest: Agribusiness; Pisciculture; Management. E-mail: raiane.rm@hotmail.com, Orcid: http://orcid.org/0000-0003-4528-744X

Gessuir Pigatto - Degree in Economy (Universidade Federal do Paraná [UFPR], Brasil), Master and Doctor of Production Engineering (Federal University of São Carlos [UFSCar], Brasil). Professor in Graduate Program in Agribusiness and Development (PGAD), São Paulo State University (UNESP). Research group leader in CNPQ: CEPEAGRO (Centro de Pesquisa em Administração e Agronegócio). Research interest: Competitiveness of Agribusiness Systems; Internationalization; Distribution Channels; Food Service. E-mail: gessuir.pigatto@unesp.br, Orcid: http://orcid.org/0000-0002-5240-2381

Timóteo Ramos Queiroz - Degree in Business Administration (Universidade Federal do Mato Grosso do Sul [UFMS], Brasil). Master and Doctor of Production Engineering (Federal University of São Carlos [UFSCar], Brasil). Professor in Graduate Program in Agribusiness and Development (PGAD), São Paulo State University (UNESP). Researcher in CEPEAGRO (Centro de Pesquisa em Administração e Agronegócio). Research interest: Network Management and Productive Chains, Competitiveness of Agribusiness Systems. E-mail: timoteo.queiroz@unesp.br, Orcid: http://orcid.org/0000-0001-9327-4462

Mário Mollo Neto - CNPq Scholarship - DT-II Productivity in Technological Development and Innovative Extension, Post-Doctorate in Biosystems Engineering, State University of Campinas, Ph.D. in Agricultural Engineering by the State University of Campinas, Master in Production Engineering by Universidade Paulista (UNIP/SP), and graduated in Industrial Electrical Engineering from São Judas Tadeu University/SP. Is Associate Professor of the Biosystems Engineering Course of the Universidade Estadual Paulista (UNESP) in TUPÃ and permanent professor of the Graduate Program in Agribusiness and Development of FCE / UNESP. E-mail: mariomollo@tupa.unesp.br, Orcid: http://orcid.org/0000-0002-8341-4190 